\title{
AN INVESTIGATION INTO SOME OF THE ADJUSTMENT PROBLEMS OF THE ADOLESCENT STUTTERER
}

\author{
Frume T. Lubinsky, B.A.Log. (RAND), M.A. (RAND). \\ Extract from a thesis submitted for the Degree of Master of Arts, at the \\ University of the Witwatersrand, fohannesburg, December, I964.
}

\section{Theoretical Discussion}

As observed in urban Western society, many aspects of adolescent development are associated with increased tension and conflict, particularly in the social sphere. Developmental tasks which are regarded as important include learning an appropriate sex role, achieving emotional independence from parents and getting along with peers."

Interaction with, and social acceptance by members of the opposite sex becomes increasingly important as the adolescent moves towards maturity. The home is an important influence in the adolescent's adjustment and increased conflict between parents and children can lead to hostility and aggression. Acceptance of the physical self, attitude towards physical appearance and anxiety about health are also factors which may influence adjustment. In addition, the emotional "lability" associated with adolescence can lead to an intensification of conflict in all the above areas of adjustment.

Perusal of the relevant data relating to the adjustment problems of the normal adolescent, and research evidence on adjustment together with awareness of the problems related to stuttering, of the social nature of stuttering, and of the relationship between frequency of stutter and communicative stress, led to the formulation of the hypothesis investigated. In essence this states that:

'The relative adjustment of adolescent stutterers is poorer than that of adolescent non-stutterers, with regard to health, home environment, emotions and social interaction, and that adjustment problems in the social and emotional areas are positively related to stuttering severity.'

\section{Experimental Study}

Aim of the Investigation. To ascertain the relative adjustment of a group of stutterers and non-stutterers in the adolescent age group, as measured by an adjustment inventory, and to determine the relationship between stuttering severity and adjustment in the areas studied.

Subjects. There were 50 stutterers in the experimental group and 50 non-stutterers in the control group. They were all between 13 and I9 
years of age and attended high schools in the Johannesburg area. Their fathers' occupations ranged from manual semi-skilled workers to professionally highly-qualified and administrative executives. Religious groups included Jews, Protestants and Catholics. The sex ratio was approximately 6 boys to I girl and the experimental group consisted of I I severe, I9 moderate and 20 mild stutterers.

Assessment Instrument. The Bell Adjustment Inventory was used. It is a paper and pencil test, and as such many criticisms have been directed against it. However, writers agree that it has better than chance validity, and it has been extensively used to measure adjustment in divergent fields of psychological research, as well as in a number of investigations in the field of speech therapy.

The inventory purports to assess the home, health, social, emotional and "total" areas of personal adjustment. Scores on the four separate measures in the Inventory are interpreted by Bell in the following way:

Home Adjustment: High scores arc indicative of unsatisfactory adjustment to home environment.

Health Adjustment: High scores are indicative of unsatisfactory health adjustment.

Social Adjustment: Individuals scoring high tend to be submissive and retiring in their social contacts, whereas low scores indicate aggressiveness in social contacts.

Emotional Adjustment: Individuals with high scores tend to be emotionally unstable. ${ }^{2}$

The test is self-administered, takes 25 minutes to complete and can be accurately scored in three minutes. A South African research worker has described it as a simple, practical tool for the investigation of adjustment."

Procedure. Subject selection was limited by the following criteria:

(a) All subjects were White South Africans.

(b) All subjects were English-speaking.

(c) None had gross sensory or motor impairment.

The goal in sampling was to obtain the maximum comparability of both groups on all the pertinent variables except stuttering. Subjects were matched according to age, religion of parents, socio-economic status in terms of fathers' occupations, educational levels as indicated by class and school progress, sex and the school which they were attending.

Subjects were only included in the control group, if the writer was satisfied that they had no speech defects of any description.

The following definition of stuttering was used as the criterion for differentiating stutterers from non-stutterers, for inclusion in the experimental group:

"Any or all of the following were regarded as speech disfluencies...

(a) Repetition of words, parts of words, phrases and sounds.

(b) Prolongation of words, parts of words, phrases and sounds.

(c) Breaks in forward flow of speech, such as blocking, stickings, grimaces and intericctions." $" 10$

Stuttering severity was rated on a nine-point rating scale, as used and recommended by Sherman and her co-workers. ${ }^{11,}{ }^{12}$

The writer visited schools in different suburbs, covering a cross-section of the community and the adjustment tests were administered during school hours. Selected subjects were told that they were helping in a 
research project, and were assured that their questionnaires would be treated confidentially.

\section{Results}

Method of Analysis. The group means in each of the adjustment areas measured were compared pair-wise. As differing variances made the use of the conventional student's " $t$ " test impossible, the modified " $t$ " test by Welch and cited in Brownlee was used. For the purpose of this study results exceeding the $5 \%$ level of significance were regarded as statistically significant. The test statistic " $t$ " with modified degrees of freedom was used to ascertain differences in mean scores between the matched groups of stutterers and controls in all the areas measured. Comparisons were also made between severe stutterers and all controls, moderate stutterers and all controls, and all stutterers and all controls. Results showed no marked difference between the responses of mild stutterers and controls. Accordingly mild stutterers' and controls' mean scores were pooled and compared with the pooled moderate and severe stutterers' mean scores.

The " $t$ " test with modified degrees of freedom was-also used to examine the effect of severity of stuttering on adjustment scores.

A contingency table of controls' and stutterers' scores in relation to Bell's norms was set up, to determine whether stutterors' and controls' scores, clustered around the area of "average", as described by Bell, or whether they respectively clustered around the "worse than average" and "better than average" scores. It was felt that this would provide information suggestive of trends in the subjects' responses to items in this test.

Analysis was also carried out with a view to finding out which of the individual questions discriminated best between stutterers and controls. Eight comparisons were made for each question and the similarity of response was tested by means of a Chi-squared test.

Discussion and Interpretation. The results of the present study indicated significant differences in the responses to items on the Bell Adjustment Inventory, between the experimental sample and the matched control group, in all adjustment areas measured. All adjustment scores excepting "home" increased with the severity of the stuttor. An interesting phenomenon was observed in the close similarity between the responses of the mild stutterers and the control group, in all areas.

Although mean scores are all within the normal range déscribed by Bell, a larger proportion of stutterers' total adjustment scores are classified as "worse than average" in terms of Bell's norms." A certain amount of "faking" by endorsement of the socially desirable response is to be expected. The observed scores may therefore be regarded as conservative estimates of the subjects' "actual" evaluation of their adjustment problems.

The stutterers" mean scores on the "home" scale of the Bell Adjustment Inventory indicate less satisfactory home adjustment than the mean scores 
of the matched non-stuttering group. The present results are in agreement with Duncan who also found a significant difference in the responses of stutterers and non-stutterers to the home scale on the Bell Adjustment Inventory. It may be feasible to presume that less satisfactory parent-child relationships between stutterers and their parents, as discussed by other workers in the field, cause adolescent stutterers to feel less well-adjusted than non-stutterers in their home surroundings.

Scores on the health scale indicate poorer adjustment of the stuttering group, and displayed a tendency to increase with stuttering severity. However, this scale appears to measure various different aspects of health, and the question as to whether physical or emotional states are influencing the test results remains largely unanswered. It is thus difficult to interpret these results, and they cannot be viewed in relation to previous work.

Significant differences were not observed between all stutterers' and all controls' mean scores in the social scale. It should, however, be noted that when comparing the pooled groups of mild stutterers' scores, plus controls' scores, versus moderate stutterers' scores, plus severe stutterers' scores, a significant difference was observed. In addition, in this area mild stutterers' responses indicate better social adjustment than those of all the controls. This leads to the assumption that the mild stutterers' scores have caused the lack of significant difference between the two major groups. This is indicative of increased "social aggressiveness" in inverse ratio to stuttering severity.

The items which showed significant values of Chi-squared in three or more comparisons, were mainly in the social area, and specifically concerned speaking to the class, in front of an audience and to strangers.

Examination of the findings in this area show that the adolescents in the experimental group who were rated as "severe" and "moderate" stutterers, appear to experience more social problems than non-stutterers and mild stutterers. Further, problems appear to be mainly concerned with "difficult" speaking situations. Results obtained in similar studies approximated those of the present study.

In the emotional area a significant difference is observed between all the stutterers' mean scores and the mean scores of their matched controls groups. More significant differences were observed in this area than in the other areas under investigation. This indicates that as measured by this test, the stutterers examined regard themselves as less "emotionally stable" than the non-stuttering sample. Stutterers' scores in this area appear to be proportionately related to stuttering severity. Emotional instability may, therefore, be said to be related to severity of stuttering symptom. Upon Chi-squared analysis the most discriminating item in this area was found to be: "Do you consider yourself rather a nervous person?" The present results tend to support the findings of Bender, using the Bernreuter Personality Inventory, as well as those of Dahlstrom and Craven, Boland, Walnut and Pizzat, who in different studies administered the M.M.P.I. to stuttering and matched control groups. ${ }^{4}$ On the other hand, there is considerable empirical evidence in disagreement with the present findings." 
In the main, however, the weight of carefully controlled experimental evidence seems to favour the opinion that stutterers experience increased adjustment difficulties of an emotional nature.

Comparisons in the total adjustment scores have yielded significant differences between all the comparisons made, with the exception of mild siutterers versus all controls, thus further substantiating the obtained difference in amount of adjustment difficulties experienced by stutterers and non-stutterers in the adolescent age group.

Scores in this area also appeared to have a positive relationship with stuttering severity. As no studies were available which employed the whole of the Bell Adjustment Inventory in a similarly designed experiment, the significance of these findings cannot be evaluated in relation to other studies.

\section{Conclusion:}

Before drawing conclusions from the obtained results, it is necessary to enumerate the limitations of the present study:

(a) The groups studied cannot be regarded as representative of the total population, as selection of subjects was largely based on availability.

(b) Test responses are dependent upon subjects' insight into, and evaluation of their own problems.

(c) Limitation of the testing instrument used and the accepted difficulties associated with measuring "adjustment"., ${ }^{6,3}$

(d) It is not possible to deduce from this study whether the observed adjustment disturbances are causally related to stuttering, or whether they are the result of the stutterers' disrupted communication.

Considering the above, it is obvious that the findings of the present study can only be regarded as superficial. However, each type of research material has its special value, and can be used to supplement other findings, thus furnishing a more complete picture of the adjustment problems association with stuttering.

- Thus, the following conclusions which are drawn from this study may contribute towards a broader understanding of the behaviour and problems of the adolescent stutterer:

(a) Although the magnitude of difference was not always large, the Bell Adjustment Inventory elicited different responses from stutterers and nonstutterers in all the areas studied. Marked differences were apparent in the emotional area, whereas the most discriminating items, emphasising "stressful" speaking situations, were observed in the social area." In addition severe and moderate stutterers' responses showed less satisfactory adjustment than the mild stutterers in all areas excepting home adjustment.

(b) Although this test does not measure frustration or anxiety, these results indicate increased emotional instability in the stuttering group, thus supporting the point of view that during adolescence the stutterer experiences more problems of an emotional nature than the "normal" adolescent. This might be due to the frustration and anxiety experienced 
in social situations, together with the general emotional "lability" of the adolescent.

(c) The severity of the stutter appears to have a marked effect on relative adjustment in the social and emotional areas during adolescence.

(d) Although the adolescent stutterers' relative adjustment to the home situation is poorer than that of the "normal" adolescent, this difference is not very great, and appears to have no relation to stuttering severity.

(e) The adolescent stutterers' adjustment as shown by the total score on this test, is poorer than that of the adolescent non-stutterers examined. This also appears to be positively related to stuttering severity.

The writer is of the opinion that the most interesting finding in the present experiment, is the manner in which the mild stutterers' responses approximated the controls' responses. This should lead to further investigation of problems of adjustment and personality attributes associated with varying degrees of stuttering severity. In terms of Bloodstein's ${ }^{3}$ developmental phases it appears that the mild stutterers in the present sample have not advanced beyond the second developmental phase, and that they do not feel markedly different from their peers. Therapists dealing with stutterers in the adolescent age group should take cognisance of 1 he varying degrees of problems which may be experienced by mild and severe stutterers, and this should be an important consideration when planning individual and group therapy.

This study has only examined the problems of the adolescent stutterer from a general point of view. It therefore becomes apparent that there is scope for further and more specific research in this field. Studies taking into account the different ethnic, cultural and sub-cultural groupings specific to South Africa might also yield interesting and useful results, which would assist in the planning of therapy.

\section{Opsomming}

Hierdie studie is gerig op 'n beter begrip van die aanpassingsprobleme waarmee die adolessent wat hakkel, te kampe het.

'n Empiriese ondersoek is angevoer, om die relatiewe aanpassing van hakkelaars en nie-hakkelaars, met betrekking tot emosionele, sosiale, huislike en gesondheids aanpassing, te ondersoek. 'n Vergelyking is ook getref met die aanpassings van matige, gemiddelde en ernstige hakkelaars.

Die bevindings dui aan dat daar in alle gebiede wat ondersoek is, verskillende reaksies uitgelok is by hakkelaars en dié wat nie hakkel nie.

Terwyl die limitasies van die studie voor oë gehou moet word, mag daar tot die gevolgtrekking gekom word dat adolessente hakkelaars meer emosionele aanpassingsprobleme ondervind. Hierdie moeilikhede, asook probleme van sosiale aanpassing, blyk in direkte verhouding te wees met die erns van die hakkel-simptoom.

\section{REFERENCES}

1. Allen, R. M. (1958): Personality Procedures. New York: Harper and Frothers. 2. Bell, H. M. (I934): Manual for the Adjustment Inveniory. Student's Form. California: Stanford University. 
3. Bloodstein, O. (I960): Development of Stuttering. II-Developmental phases. J. S. H. D., 25, 219.

4. Bloodstein, O. (I959): A Handbook on Stuttering for Professional Workers. Chicago: National Society for Crippled Children and Adults Inc.

5. Brownlee, K. A. (1960): Statistical Theory and Methodology in Science and Engineering. New York: John Wiley and Sons.

6. Davidson, H. H. and Gottlieb, L. S. (I955): Emotional Maturity of Pre- and Post-Menarche Girls. J. Genetic Psychol., 86, 26r.

7. Duncan, H. M. (1949): Home Adjustment of Stutterers versus Non-Stutterers. J. S. H. D., 14, 255 .

8. Havighurst, R. J. (1956): Research on the Developmental Task Concept. School Review, 64, 215 .

9. Holtz, S. (1959): A Factor Analysis of Temperament and Personality. M.A. Thesis, University of the Witwatersrand, Johannesburg, South Africa.

10. Johnson, W. (1961): Measurement of Oral Reading and Speaking Rate and Disfiuency of Adult Male and Female Stutterers and Non-Stutterers. J. S. H. D. Monograph Supplement, 71.

II. Sherman, D. (1952): Clinical and Experimental Use of the Iowa Scale of Severity of Stuttering. J. S. H. D., 17, 316 .

I2. Sherman, D. (1955): Reliability and Utility of Individual Ratings of Severity of Audible Characteristics of Stuttering. J. S. H. D., 20, I I.

13. Tindall, R. H. (1959): Relarionships among Measures of Adjustment in Readings in The Psychology of Adjustment. New York: McGraw-Hill Book Company, Inc.

Fournal of the South African Logopedic Society, Vol. 13, No. I: May' 1966 